\title{
Fetuin-A as a Marker of Insulin Resistance in Type 2 Diabetic Patients in Zagazig University \\ Fawzy Abdelfatah El-Messallamy ${ }^{1}$, Jehan Saeed Abdo Soliman ${ }^{2}$, Sally Mahmoud Saeed Shalaby ${ }^{3}$, Heba Abdel-Rahman Kamel Abdel-Rahman*3 \\ ${ }^{1}$ Department of Internal Medicine, ${ }^{2}$ Department of Biochemistry, Faculty of Medicine, Zagazig University, Sharkia, ${ }^{3}$ Department of Internal Medicine, Faculty of Medicine, Banha University, Qaluobya, Egypt \\ *Corresponding author: Heba Abdel-Rahman Kamel Abdel-Rahman \\ Mobile: (+20) 01068028415; E-mail: lwjywlarawkarma@gmail.com
}

\begin{abstract}
Background: Fetuin-A is responsible for instigating insulin resistance by inhibiting tyrosine kinase receptors. Objective: To investigate the relationship of fetuin-A with and insulin resistance in type- II diabetics either obese or non-obese of Zagazig University, Shatkia Governorate, Egypt.

Patients and Methods: This is a case-control study that was conducted at the Internal Medicine Department of Zagazig University. Seventy-five participants were divided into three groups. Group-A $(n=25)$ normal healthy individual, Group-B ( $\mathrm{n}=25)$ non-obese type 2 diabetic patients and Group $\mathrm{C}(\mathrm{n}=25)$ obese type 2 diabetic patients. Type 2 diabetic patients with no morbidities. Serum fetuin-A and insulin levels were performed by ELISA kits while fasting blood glucose (FBG), 2HPP and HA1C were determined by the enzymatic kit method. A comparison of groups was done and correlation was achieved by using Spearman correlation.

Results: The results demonstrated a significant difference in mean values of fetuin-A, BMI, WHR, fasting blood glucose (FBG), 2HPP, HA1C, insulin level and Homoeostasis Model Assessment of Insulin resistance (HOMAIR) in type-II diabetics when compared to normal healthy individuals and obese type-II diabetics $(\mathrm{p}<0.01)$. The fetuin-A level was higher in obese more than non-obese type II diabetics.

Conclusion: The study concluded that fetuin-A might be accountable for insulin resistance in type-II diabetes mellitus either obese or non-obese. So the high levels of Fetuin-A responsible for insulin resistance.
\end{abstract}

Keywords: Fetuin-A, Insulin Resistance, Type-II Diabetes Mellitus, Obesity, HOMA-IR.

\section{INTRODUCTION}

Type-II diabetes mellitus is a complex metabolic disorder characterized by persistent hyperglycemia due to deficiency of insulin production or peripheral tissue resistance to in action. Long term hyperglycemia is responsible for affecting the structural and functional comorbidities, which gives rise to complications like diabetic neuropathy, nephropathy, retinopathy, hypertension, hyperlipidemia, cerebrovascular diseases and atherosclerotic coronary heart disease ${ }^{(\mathbf{1})}$.

Fetuin-A is a multifunctional plasma factor that secreted mainly by hepatocytes, also called Alpha 2Heremans Schmid Glycoprotein (AHSG) ${ }^{(2)}$, FetuinA act by inhibition of insulin receptor tyrosine kinase activity and this is related to insulin resistance, metabolic syndrome and increased risk of type-II diabetes mellitus ${ }^{(3)}$.

Fetuin-A blocks the insulin from attaching to its receptors, creates a pathway and causes insulin resistance concerning type-II diabetes mellitus pathophysiology. Fetuin-A gene is discovered at the locus 27 on the (q) arm of chromosome 3, which is also related to type-II diabetes mellitus and cardiometabolic disorders ${ }^{(4)}$.

Metabolic syndrome is related to many underlying mechanisms as insulin resistance, inflammation, hormonal changes, and decreased physical activity ${ }^{(5)}$.

Studies have shown a strong association inhibitory effect of fetuin-A on adipose tissue, lipolysis and free fatty acid efflux ${ }^{(6)}$.
Obesity is caused by a chronic energy imbalance, increased dietary intake and low physical activity. Obesity plays an important role in increased risk of Type-II diabetes, cardiovascular diseases, and cancer ${ }^{(7)}$. The beneficial effects of moderate weight loss (5\%-10\%) on hyperglycemia, hyperinsulinemia, hyperlipidemia, and insulin resistance are well documented ${ }^{(8)}$. Diabetes Prevention Program (DPP), has demonstrated that lifestyle intervention with modest weight loss decreased the incidence of T2DM and delayed the progression from obesity to $\mathrm{T}^{2} \mathrm{DM}^{(9)}$.

To best of our knowledge, there is a great relationship between fetuin-A and insulin resistance in type-II diabetic patients either obese or non-obese.

\section{AIM OF THE STUDY}

The present study aimed to investigate the level of fetuin-A levels in obese and non-obese type 2 diabetes mellitus patients.

\section{PATIENTS AND METHODS}

This is a case-control study that carried out on 75 participants admitted to the Internal Medicine Department at Zagazig University Hospitals. The participants were divided into three groups: Group1: 25 non-obese non-diabetic individuals, Group 2: 25 non-obese Type-II diabetic patients and Group 3: 25 obese Type-II diabetic patients. 
Patients inclusion criteria: Type 2 diabetic patient. Age equal or more than 35 years old and both genders were included.

\section{The following patients were excluded:}

Type 1 DM. Gestational diabetes. Smokers. Patients with CNS complications. Chest diseases asthma, COPD or T.B. Chronic kidney disease patient. Chronic liver disease patient, Hepatitis C, B and Non-alcoholic fatty liver disease (NAFLD). Ischemic heart disease patient and Hypertensive patient. Hypo and hyperthyroidism. Any acute inflammatory condition that may affect Serum fetuin -A level and dyslipidemia (serum cholesterol concentration $>220 \mathrm{mg} / \mathrm{dL}$ or serum triglyceride concentration $>150 \mathrm{mg} / \mathrm{dl}$ ).

The study was conducted following the Declaration of Helsinki. All participants provided written informed consent, and the Ethics Committee of Faculty of Medicine, Zagazig University approved the study protocol.

Ethical consideration and Written informed consent:

An approval of the study was obtained from Zagazig University academic and ethical committee. Every patient signed an informed written consent for acceptance of the operation.

\section{All patients in the study were subjected to the} following:

1) Full history and thorough clinical examination.

2) Family history of diabetes mellitus, hypertension, and obesity.

3) General clinical examination; anthropometric measurement including waist and hip circumference in $\mathrm{cm}$, weight in $\mathrm{kg}$, and height in $\mathrm{cm}$; Calculation of the body mass index BMI calculated as weight in kilograms divided by square of height in meters. $(\mathrm{BMI}=$ Weight $(\mathrm{Kg})=$ $\mathrm{Kg} / \mathrm{m}^{2}$ Height $\left.(\mathrm{m})^{2}\right)$.

4) Routine laboratory tests: Including Urine analysis: (for glucose, acetone, protein, $\mathrm{pH}$, and albumin). Complete blood picture - red blood cell count(RBC), hemoglobin level, hematocrit value, white blood cell (WBC) count and platelet count. Liver function tests (S. albumin, ALT and AST). Kidney function test (S. Urea and S.Creatinin). TSH. CRP. Total Ca and Mg. and blood sugar blood glucose measurements, FBS, 2HPP, $\mathrm{HbA} 1 \mathrm{C}$ or RBS.

5) Imaging: ECG, Echocardiography , Chest $x$-ray, and abdominopelvic ultrasound.

6) Specific investigations:

Insulin level: Fasting Insulin levels were measured using the Enzyme Linked Immunosorbent Assay (ELISA kits). Immunospec Insulin is a solid phase enzyme-linked immunosorbent assay (ELISA). The wells are coated with a monoclonal antibody with higher activity for insulin. HOMA was calculated using the formula (fasting insulin $(\mathrm{mIU} / \mathrm{ml}) \mathrm{x}$ fasting glucose $(\mathrm{mmol} / \mathrm{l})) / 22.5$.

Serum fetuin-a level: This ELISA (enzyme-linked immunosorbent assay) kit is intended for the quantitative determination of human Fetuin-A, also known as alpha-2-HS glycoprotein (AHSG), in serum, plasma (EDTA or Heparin), cell culture supernatant, tissue extraction, and urine.

\section{Statistical Analysis}

All data were collected, tabulated and statistically analyzed using SPSS 22.0 for windows (SPSS Inc., Chicago, IL, USA) and Microsoft Office Excel 2010 for windows (Microsoft Cor., Redmond, WA, USA). Continuous variables were expressed as the mean \pm SD and the categorical variables were expressed as a number (percentage). Continuous variables were checked for normality by using the Shapiro-Wilk test. Wilcoxon signed ranks test was used to compare two dependent groups of nonnormally distributed variables. All tests were twosided. P-value $<0.05$ was considered statistically significant, $\mathrm{p}$-value $<0.001$ was considered highly statistically significant, and p-value $\geq 0.05$ was considered statistically insignificant (NS). 
RESULTS

Table (1): Comparison of some demographic parameters among studied groups.

\begin{tabular}{|c|c|c|c|c|c|}
\hline & $\begin{array}{l}\text { Group 1 } \\
(\text { Control }) \\
(\mathbf{n}=\mathbf{2 5})\end{array}$ & $\begin{array}{c}\text { Group2 } \\
\text { (Non obese type2 } \\
\text { diabetes) }(n=25)\end{array}$ & $\begin{array}{l}\text { Group3 (Obese } \\
\text { type2 diabetes) } \\
(n=25)\end{array}$ & $\begin{array}{l}\text { Test of } \\
\text { significance } \\
\text { (f) }\end{array}$ & P-value \\
\hline $\begin{array}{l}\text { Age (years) }(\mathrm{X} \pm \mathrm{SD}) \\
\text { Range }\end{array}$ & $\begin{array}{c}48.5 \pm 4.4 \\
(40-55)\end{array}$ & $\begin{array}{c}52.6 \pm 8.5 \\
(42-69)\end{array}$ & $\begin{array}{c}49.4 \pm 6.9 \\
(38-66)\end{array}$ & 2.5 & 0.08 \\
\hline $\begin{array}{l}\mathbf{B M I}\left(\mathbf{k g} / \mathbf{m}^{2}\right) \\
(\mathrm{X} \pm \mathrm{SD}) \\
\text { Range }\end{array}$ & $\begin{array}{c}21.0 \pm 2.2 \\
(18-27)\end{array}$ & $21.6 \pm 1.6(18-24)$ & $\begin{array}{c}31.7 \pm 3.3 *(27- \\
42)\end{array}$ & 140.0 & $<0.001 * *$ \\
\hline $\begin{array}{l}\text { WHR(m) }(\mathrm{X} \pm \mathrm{SD}) \\
\text { Range }\end{array}$ & $\begin{array}{c}0.87 \pm 0.04 \\
(0.77-0.95)\end{array}$ & $\begin{array}{l}1.03 \pm 0.06 \\
(0.89-1.13)\end{array}$ & $\begin{array}{c}1.09 \pm 0.05(1.0- \\
1.13)\end{array}$ & 53.9 & $<0.001 * *$ \\
\hline $\begin{array}{l}\text { Sex } \\
\text { Male } \\
\text { Female }\end{array}$ & $\begin{array}{l}12(48.0 \%) \\
13(52.0 \%)\end{array}$ & $\begin{array}{l}13(52.0 \%) \\
12(48.0 \%)\end{array}$ & $\begin{array}{l}10(40.0 \%) \\
15(40.0 \%)\end{array}$ & $X^{2} 0.7$ & 0.68 \\
\hline $\begin{array}{l}\text { Family history of type } 2 \\
\text { DM } \\
+V E \\
-V E\end{array}$ & $\begin{array}{l}10(40.0 \%) \\
15(60.0 \%)\end{array}$ & $\begin{array}{c}20(80.0 \%) \\
5(20.0 \%)\end{array}$ & $\begin{array}{c}20(80.0 \%) \\
5(20.0 \%)\end{array}$ & 7.66 & $0.022 *$ \\
\hline
\end{tabular}

WHR= Waist hip ratio

There was a statistically highly significant difference in BMI and WHR (P value $<0.001$ ), also there was a statistically significant difference as regard family history for diabetes (P-value <0.05), but there was no statistically significant difference in age and sex as regard (P-value $>0.05)$.

Table (2): Comparison of systolic and diastolic blood pressure among the studied groups by ANOVA test.

\begin{tabular}{|c|c|c|c|c|c|}
\hline & $\begin{array}{c}\text { Group1 } \\
(n=25)\end{array}$ & $\begin{array}{c}\text { Group2 } \\
(n=25)\end{array}$ & Group3 $(n=25)$ & $\begin{array}{c}\text { Test of } \\
\text { significance(f) }\end{array}$ & P-value \\
\hline $\begin{array}{l}\text { Systolic Blood pressure } \\
(\mathbf{m m} \mathbf{H g})(\mathrm{X} \pm \mathrm{SD}) \\
\text { Range }\end{array}$ & $\begin{array}{l}115 \pm 4.1 \\
(110-120)\end{array}$ & $\begin{array}{l}124.6 \pm 3.2 \\
(120-130)\end{array}$ & $\begin{array}{l}141.2 \pm 11 \\
(130-157)\end{array}$ & 83.0 & $<0.001 * *$ \\
\hline $\begin{array}{l}\text { Diastolic Blood pressure } \\
(\mathbf{m m} \mathbf{H g})(\mathrm{X} \pm \mathrm{SD}) \\
\text { Range }\end{array}$ & $\begin{array}{c}75.7 \pm 3.7 \\
(70-81)\end{array}$ & $\begin{array}{c}78.4 \pm 1.8 \\
(75-83)\end{array}$ & $\begin{array}{l}80 \pm 3.0 \\
(75-88)\end{array}$ & 29.1 & $<0.001 * *$ \\
\hline
\end{tabular}

There was a statistically highly significant difference in the mean values \pm SD of systolic and diastolic blood pressure $(\mathrm{BP} / \mathrm{mm} \mathrm{Hg})$ as $(\mathrm{P}$-value $<0.001)$ in between studied groups.

Table (3): Comparison of laboratory parameters (liver functions, kidney functions, and HB level) among different groups of the study using the ANOVA test.

\begin{tabular}{|c|c|c|c|c|c|}
\hline & Group1 $(\mathrm{n}=25)$ & Group2 $(\mathrm{n}=25)$ & Group3 $(n=25)$ & $\begin{array}{c}\text { Test of } \\
\text { significance (f) }\end{array}$ & $P$-value \\
\hline $\begin{array}{l}\text { Albumin }(\mathbf{g m} / \mathrm{L})(\mathrm{X} \pm \mathrm{SD}) \\
\text { Range }\end{array}$ & $\begin{array}{c}4.3 \pm 0.2 \\
(4.23-4.7)\end{array}$ & $\begin{array}{c}3.9 \pm 0.2 \\
(3.64-4.14)\end{array}$ & $\begin{array}{c}4.1 \pm 0.2 \\
3.88-4.34)\end{array}$ & 20.0 & $<0.001 * *$ \\
\hline $\begin{array}{l}\text { ALT }(\mathbf{U} / \mathbf{L})(\mathrm{X} \pm \mathrm{SD}) \\
\text { Range }\end{array}$ & $\begin{array}{l}24.5 \pm 1.8 \\
(23-27.3)\end{array}$ & $\begin{array}{c}22.9 \pm 2.3 \\
(20.01-26)\end{array}$ & $\begin{array}{c}24.5 \pm 1.9 \\
(23-30)\end{array}$ & 5.2 & $0.007 *$ \\
\hline $\begin{array}{l}\text { AST (U/L) }(\mathrm{X} \pm \mathrm{SD}) \\
\text { Range }\end{array}$ & $\begin{array}{c}24.4 \pm 2.3 \\
(23.6-30.1)\end{array}$ & $\begin{array}{c}24 \pm 2.4 \\
(19.9-28)\end{array}$ & $\begin{array}{c}27.6 \pm 2.8 \\
(23-33)\end{array}$ & 13.6 & $<0.001 * *$ \\
\hline $\begin{array}{l}\text { Urea(mg/dl ) }(\mathrm{X} \pm \mathrm{SD}) \\
\text { Range }\end{array}$ & $\begin{array}{l}29.5 \pm 1.98 \\
(25-33)\end{array}$ & $\begin{array}{l}35.1 \pm 2.5 \\
(28-38)\end{array}$ & $\begin{array}{c}39.4 \pm 1.8 \\
(36-43)\end{array}$ & 134.3 & $<0.001 * *$ \\
\hline $\begin{array}{l}\text { Creatinin(mg/dl) }(\mathrm{X} \pm \mathrm{SD}) \\
\text { Range }\end{array}$ & $\begin{array}{c}1.07 \pm 0.06 \\
0.8-1.1)\end{array}$ & $\begin{array}{l}1.0 \pm 0.05 \\
(0.85-1.1)\end{array}$ & $\begin{array}{l}1.2 \pm 0.1 \\
(1-1.5)\end{array}$ & 38.7 & $<0.001 * *$ \\
\hline HB (g/dl) $\mathrm{X} \pm \mathrm{SD}$ & $12.9800 \pm 1.47561$ & $11.7842 \pm 2.04962$ & $11.4462 \pm 1.87866$ & 0.811 & 0.573 \\
\hline
\end{tabular}

There was a statistically highly significant difference in the mean values \pm SD of blood urea, serum creatinine, S.Albumin and AST ( $<<0.001)$ Also there was a statistically significant difference as regard (ALT) (P-value <0.05), but there was no statistically significant difference as regard HB level (P-value $>0.05)$. 
Table (4): Comparison of some glycemic parameters among studied groups by ANOVA test.

\begin{tabular}{|l|c|c|c|c|c|}
\hline & $\begin{array}{c}\text { Group1 } \\
(\mathbf{n = 2 5})\end{array}$ & Group2 $(\mathbf{n = 2 5})$ & Group3 $(\mathbf{n = 2 5})$ & $\begin{array}{c}\text { Test of } \\
\text { significance (f) }\end{array}$ & P-value \\
\hline FBS $(\mathbf{m g} / \mathbf{d l})(\mathrm{X} \pm \mathrm{SD})$ & $94.8^{*} \pm 11.7$ & $150.7^{*} \pm 13.5$ & $177.6 \pm 40.9$ & 66.9 & $<0.001^{* *}$ \\
\hline 2HPP(mg/dl) $(\mathrm{X} \pm \mathrm{SD})$ & $143^{*} \pm 8.7$ & $196.3^{*} \pm 4$ & $273.5 \pm 66$ & 51.2 & $<0.001^{* *}$ \\
\hline HA1C\% $(\mathrm{X} \pm \mathrm{SD})$ & $5.1 \pm 0.4$ & $7.1 \pm 0.5$ & $8.4 \pm 0.9$ & 60.8 & $<0.001^{* *}$ \\
\hline $\begin{array}{l}\text { Insulin level }(\mathbf{I u} / \mathbf{m l}) \\
(\mathrm{X} \pm \text { SD) }\end{array}$ & $6.2 \pm 0.6$ & $16.7 \pm 0.9$ & $26.1 \pm 1.5$ & 65.8 & $<0.001^{* *}$ \\
\hline HOMA-IR $(\mathrm{X} \pm \mathrm{SD})$ & $1.45 \pm 0.2$ & $6.4 \pm 0.3$ & $11.4 \pm 0.4$ & 65.8 & $<0.001^{* *}$ \\
\hline
\end{tabular}

There was a statistically highly significant difference in the mean values \pm SD of fasting blood glucose, postprandial blood glucose, HbA1C\%, Insulin level, and HOMA-IR among the studied groups $(\mathrm{p}<0.001)$.

Table (5): Comparison of the TSH, Total CalMg and CRP among studied groups using ANOVA test.

\begin{tabular}{|c|c|c|c|c|c|}
\hline & $\begin{array}{c}\text { Group } 1 \\
(n=25)\end{array}$ & $\begin{array}{c}\text { Group } 2 \\
(n=25)\end{array}$ & $\begin{array}{c}\text { Group } 3 \\
(n=25)\end{array}$ & $\begin{array}{c}\text { Test of } \\
\text { significant (f) }\end{array}$ & P-value \\
\hline TSH (mlul) $(\mathrm{X} \pm \mathrm{SD})$ & $3.9 \pm 0.7$ & $2.8 \pm 0.09$ & $1.49 \pm 0.06$ & 63.4 & $<0.001 * *$ \\
\hline Total.CalMg $(\mathrm{X} \pm \mathrm{SD})$ & $2.6 \pm 0.1$ & $3.0 \pm 0.11$ & $3.4 \pm 0.14$ & 66.9 & $<0.001 * *$ \\
\hline CRP(mlull) $(\mathrm{X} \pm \mathrm{SD})$ & $1.4 \pm 0.1$ & $1.53 \pm 0.1$ & $1.87 \pm 0.2$ & 51.2 & $<0.001 * *$ \\
\hline
\end{tabular}

There was a statistically highly significant difference in the mean values \pm SD of TSH, total CalMg and CRP (P-value $<0.001$ ) in between studied groups.

Table (6): Comparison of the serum fetuin-A (ng/ml) level among studied groups by ANOVA test.

\begin{tabular}{|l|c|c|c|c|c|}
\hline & $\begin{array}{c}\text { Group1 } \\
(\mathbf{n = 2 5})\end{array}$ & $\begin{array}{c}\text { Group2 } \\
(\mathbf{n = 2 5})\end{array}$ & $\begin{array}{c}\text { Group3 } \\
(\mathbf{n = 2 5})\end{array}$ & $\begin{array}{c}\text { Test of } \\
\text { significant (f) }\end{array}$ & P-value \\
\hline Serum fetuin-A (ng/ml) $(\mathrm{X} \pm \mathrm{SD})$ & $258.0 * \pm 18.0$ & $326.1 * \pm 20.1$ & $361.6 \pm 19.5$ & & \\
Range & $(223-300.2)$ & $(298-364.1)$ & $(325-391.3)$ & 187.0 & $<0.001^{* *}$ \\
\hline
\end{tabular}

There was a statistically highly significant difference in the mean values $\pm \mathrm{SD}$ of serum fetuin-A $(\mathrm{ng} / \mathrm{ml})$ distribution between studied groups (P-value <0.001).

Table (7): Correlations between Serum fetuin-A and some parameters and clinical variables of the study.

\begin{tabular}{|c|c|c|c|c|}
\hline \multirow{3}{*}{ Insulin level(Iu/ml) } & \multirow{2}{*}{\multicolumn{2}{|c|}{$\begin{array}{l}\text { Group 2:Non obeseT2DM } \\
\mathbf{R}\end{array}$}} & \multicolumn{2}{|c|}{ Group3: obese T2DM } \\
\hline & & & $\mathbf{R}$ & $\mathbf{P}$ \\
\hline & 0.56 & $<0.001 * *$ & -0.34 & $<0.001 * *$ \\
\hline Insulin/glucose & 0.36 & $<0.05^{*}$ & -0.28 & $>0.05$ \\
\hline HOMA-IR & 0.55 & $<0.001 * *$ & 0.0 .5 & $<0.001 * *$ \\
\hline FBG (mg/dl) & 0.128 & 0.062 & 0.225 & 0.003 \\
\hline 2-H PP (mg/dl) & 0.093 & 0.172 & 0.215 & 0.012 \\
\hline HA1C(\%) & 0.098 & 0.151 & 0.312 & $<0.001 * *$ \\
\hline BMI $\left(\mathrm{kg} / \mathrm{m}^{2}\right)$ & 0.47 & $<0.05 *$. & 0.63 & $<0.001 * *$ \\
\hline Age (years) & 0.118 & 0.086 & 0.179 & 0.039 \\
\hline Waist - hip ratio & 0.110 & 0.111 & 0.188 & 0.030 \\
\hline S BP (mmHg) & 0.048 & 0.484 & 0.090 & 0.299 \\
\hline DBP (mmHg & 0.062 & 0.371 & 0.112 & 0.198 \\
\hline Cholesterol (mg/dl) & 0.082 & 0.237 & 0.209 & 0.016 \\
\hline Triglyceride (mg/dl) & 0.091 & 0.190 & 0.287 & $<0.001 * *$ \\
\hline HDL(mg/dl) & -0.041 & 0.557 & -0.163 & 0.058 \\
\hline LDL (mg/dl) & 0.39 & $<0.05 *$ & 0.13 & $>0.05$ \\
\hline CRP(mlull) & 0.103 & 0.134 & 0.043 & $<0.001 * *$ \\
\hline TSH(mlul) & 0.63 & $<0.001 * *$ & -0.34 & $<0.001 * *$ \\
\hline
\end{tabular}

There was a statistically significant positive correlation between serum fetuin-A level and Insulin level, HOMA-IR, HA1C, LDL, BMI and TSH in non-obese type2 diabetic patients. Also, there was a statistically significant positive correlation between serum fetuin-A level and HOMA-IR, BMI, HA1C and CRP in obese type 2 diabetic patients. Also, there was a statistically significant negative correlation between serum fetuin-A level and Insulin level, TSH and HDL level in obese type 2 diabetic patients. But there was no statistically significant correlation between serum fetuin-A level and age, WHR, FBG, 2HPP, SBP, DBP and TC in non-obese and obese type 2 diabetic patients. 


\section{DISCUSSION}

In the present study, there was a statistically highly significant difference in between studied groups as regard to BMI and WHR as ( $\mathrm{P}$ value $<0.001)$, an increase in BMI and WHR in obese type 2 diabetes patients in comparison to non-obese type 2 diabetes patients, and with correlation there was a statistically significant positive correlation between serum fetuin-A level and BMI in obese type 2 diabetic patients but there was no statistically significant correlation between serum fetuin-A level and BMI in non-obese type 2 diabetic patients no correlation between serum fetuin-A level, age and WHR. Fetuin-A was high in type 2 diabetes with obesity more than type2diabetes without obesity, Also there was a statistically significant difference as regard family history for diabetes (P-value $<0.05$ ). But there was no statistically significant difference in age and sex as regard (P-value $>0.05$ ) as they were at the same age, the age ranged from 35 to 70 years old with life peaking at the six-decade.

In this study, there was a statistically highly significant difference regarding systolic and diastolic blood pressure distribution between studied groups (P-value $<0.001$ ). This explained by damaging of normal function of endothelium and platelets is well associated with hyperglycemia, arterial calcification, dyslipidemia, and insulin resistance lead to inflammation, vasoconstriction, thrombosis with increase the risk of atherosclerosis (10).

This is in agreement with Chung $\boldsymbol{e t}$ al. (11) who reported that serum fetuin-A levels showed a significant positive correlation with systolic blood pressure (BP).

Also, this was in agreement with Chatterjee et al. ${ }^{\left({ }^{(12)}\right.}$ reported that serum fetuin-A concentration was positively correlated with BMI, WHR, systolic and diastolic blood pressure. In our study, there was a statistically highly significant difference in the mean values \pm SD of blood urea, serum creatinine, S. Albumin and AST ( $p<0.001)$. Also, there was a statistically significant difference as regard (ALT) (P-value $<0.05$ ) but there was no statistically significant difference as regard $\mathrm{HB}$ level as regard ( $\mathrm{P}$-value $>0.05$ ).

In this study, glycemic parameters distribution among studied groups. There was a statistically highly significant difference in between studied groups as regard to FBS, 2HPP and $\mathrm{HbA} 1 \mathrm{C}$ as ( $\mathrm{P}$-value $<0.001)$. High glycemic parameters in type 2 diabetic patients either obese or non-obese and incomparable to the control group. Also, there were statistically high significant values in comparison between obese and non-obese type 2 diabetic patients, also there was a non-significant positive correlation between serum fetuin-A and FBS, 2HPP and significant positive correlation between serum fetuin-A and $\mathrm{HbA} 1 \mathrm{C}$ in a comparison between obese and nonobese type 2 diabetes type 2 diabetic patients. This in agreement with Zhou et al. ${ }^{(13)}$, who reported that there was a correlation between fetuin-A and other clinical variables among studied groups. Fetuin-A was correlated positively with FPG, HbA1c, and HOMA-IR.

In this study, insulin resistance parameter distribution among studied groups shows there was a statistically highly significant difference between studied groups as regard to fasting insulin level and HOMA-IR as (P-value $<0.001$ ). High insulin resistance parameters in nonobese type 2 diabetes and obese type 2 diabetes were incomparable to the control group. Also, there were statistically high significant values in a comparison between obese and non-obese type2 diabetes. Also, there was a significant positive correlation between serum fetuin-A level and insulin level, insulin glucose ratio and HOMA-IR in obese type 2 diabetic patients and non-obese type 2 diabetic patients. As fetuin-A inhibits phosphorylation of the insulin receptors in the liver and muscle leads to a decrease in insulin signaling resulted in insulin resistance in type 2 diabetes. Fetuin-A promotes insulin resistance by inhibition of the insulin receptor tyrosine kinase by mediating free fatty acid inflammatory signaling through tolllike receptor increase fat accumulation, FFAmediated inflammation of the beta-cells in the pancreas contributing to insulin resistance. Olivia et al. (14), this is another pathophysiology with obese type 2 diabetes explain high insulin resistance parameters in non-obese type 2 diabetes and obese type 2 diabetes incomparable to control group .also there was statistically high significant values in the comparison between obese and nonobese type 2 diabetes and that with this study.

This study showed a statistically highly significant difference in the mean values $\pm \mathrm{SD}$ of TSH, Total CalMg and CRP (P-value <0.001)in between studied groups, statistically high significant values in TSH and Total Calmg in nonobese type2diabetes and obese type2diabetes incomparable to control group. Also, there were high significant values in non-obese type 2 diabetes as compared to obese type 2 diabetes which can be explained by serum level of fetuin-A is negatively associated with $\log$ transformation levels of thyroid-stimulating hormone in patients with hyperthyroidism or euthyroidism.

High serum fetuin-A concentration was related to high thyroid function. Verras et al. ${ }^{(15)}$ This in agreement with Šimják et al. (16), In humans, high serum fetuin-A level was found to be positively associated with metabolic syndrome and 
CRP, suggesting that fetuin-A may be causally involved in the pathophysiology of the condition of subclinical inflammation.

This in agreement with Ammar et al. ${ }^{(17)}$, fetuin-A was correlated positively with the Homeostasis Model of Assessment-Insulin Resistance, High-sensitivity C-reactive protein, fT3, and fT4, as there was a negative correlation between thyroid-stimulating hormone and fetuin-A.

This study showed that fetuin-A level mean $\pm \mathrm{SD}$ was distributed as $258.0^{*} \pm 18.0 \mathrm{ng} / \mathrm{ml}$ (the level ranged from 223 to $300.2 \mathrm{ng} / \mathrm{ml}$ ) for the control group, $326.1 * \pm 20.1 \mathrm{ng} / \mathrm{ml}$ (the level ranged from 298 to $364.1 \mathrm{ng} / \mathrm{ml}$ ) for group2 (non-obese type 2 diabetes) and $361.6 \pm 19.5 \mathrm{ng} / \mathrm{ml}$ (the level ranged from $325-391.3 \mathrm{ng} / \mathrm{ml}$ ) for group3 (obese type 2 diabetes). And also There was high serum fetuinA level in non-obese type2diabetic patients and obese type2diabetic patients in comparison to the control group and also high serum fetuin-A level in non-obese type 2 diabetic patients in comparison to obese type2diabetic patients. Also this study show there was a statistically significant positive correlation between serum fetuin-A level and Insulin level, Insulin|glucose, HOMA-IR, HbA1C, LDL in non-obese type 2 diabetic patients .also there was a statistically significant positive correlation between serum fetuin-A level and HOMA-IR, BMI, HA1C and CRP in obese type2 diabetic patients. Also there was a statistically significant negative correlation between serum fetuin-A level and Insulin level and TSH level in obese type 2 diabetic patients .but there was no statistically significant correlation between serum fetuin-A level and age, WHR, FBG,2HPP, SBP and DBP in obese and non-obese type2 diabetic patients.

Shimoda et al. ${ }^{(18)}$, reported that recent research observed that fetuin-A may be involved in the pathogenesis of obesity-related T2DM rather than non-obese T2DM. So, in conclusion, this study showed that obese T2DM patients had higher fetuin-A levels compared with non-obese patients and obese NGT subjects, and the associations between fetuin-A and obesity were more significant in T2DM patients than those in NGT subjects. This study showed higher fetuin-A level was correlated with obesity and obesity-related T2DM, but not non-obese T2DM.

In this study, there were statistically high significant correlations found between fetuin-A and other parameters of insulin resistance including HOMA-IR, FFA, TG, TC, LDL, CRP and BMI in non-obese T2DM and obese T2DM in comparison to control group and also high lipid profile parameters in non-obese type2diabetic patients in comparison to obese type2diabetic patients.

Also, this was in agreement with Liang et al. ${ }^{(19)}$, who reported that Pearson's correlation analysis was performed to assess relationships between plasma Fetuin-A levels and clinical parameters. Plasma Fetuin-A levels were found to correlate positively and significantly with HOMAIR (P < 0.01), HbA1c, SBP, LDL-C, triglyceride, and $2 \mathrm{~h}$ OGTT but negatively with FINS, PINS, HDL-C) and HOMA-IS.

There were no limitations to this study.

\section{CONCLUSION}

Our results demonstrated that serum fetuinA is higher in obese type2diabetic patients than non-obese type2diabetic patients and control group. The significant correlation between serum fetuin-A level and parameters of insulin-resistant suggests the role of its measurement as a marker for insulin resistance in type2diabetic patients.

\section{Conflict of interest: No \\ Financial disclosure: No}

\section{REFERENCES}

1. Chawla A, Chawla R, Jaggi $S$ (2016): Microvascular and macrovascular complications in diabetes mellitus: distinct or continuum?. Indian J Endocrinol Metab., 20(4):546-551.

2. Mori K, Emoto M, Inaba M (2011): Fetuin-A a multifunctional protein. Recent Pat Endocr Metab Immune Drud Discov., 5(2):124-146.

3. Bourebaba L, Marycz K (2019): Pathophysiological Implication of Fetuin-A Glycoprotein in the Development of Metabolic Disorders: A Concise Review. Journal of Clinical Medicine, 8(12):2033.

4. Fatima F, Ahsan N, Nasim A et al. (2020): Association of fetuin-A with dyslipidemia and insulin resistance in type-II Diabetics of Pakistani population. Pak J Med Sci., 36(2):64-68.

5. Heindel JJ, Blumberg B (2019): Environmental Obesogens: Mechanisms and Controversies. Annu Rev Pharmacol Toxicol., 06: 59:89-106.

6. Bernardi S, Marcuzzi A, Piscianz E et al. (2018): The Complex Interplay between Lipids, Immune System and Interleukins in Cardio-Metabolic Diseases. Int J Mol Sci., 19: 4058..

7. Blüher M (2019): Obesity. Global epidemiology and pathogenesis. Nature Reviews Endocrinology, 15: 288 298. 
8. Ormazabal V, Nair S, Elfeky O et al. (2018): Association between insulin resistance and the development of the cardiovascular disease. Cardiovasc Diabetol., 17:122-26.

9. American Diabetes Association (2019): Obesity Management for the Treatment of Type 2 Diabetes: Standards of Medical Care in Diabetes2019. Diabetes Care, 42(1): 81-89.

10. Kim K, Park SM (2018): Association of muscle mass and fat mass with insulin resistance and the prevalence of metabolic syndrome in Korean adults: a crosssectional study. Sci Rep., 8(1):2703-2706.

11. Chung HS, Lee HJ, Hwang SY et al. (2018): Relationship of Circulating Fetuin-A Levels with Body Size and Metabolic Phenotypes. International Journal of Endocrinology, 8: 7918714.

12. Chatterjee $P$, Seal $S$, Mukherjee $S$ et al. (2013): Adipocyte fetuin-A contributes to macrophage migration into adipose tissue and polarization of macrophages. The Journal of Biological Chemistry, 288(39): 28324-28330.

13. Zhou ZW, Ju HX, Sun MZ et al. (2018): Serum fetuin-A levels in obese and non-obese subjects with and without type 2 diabetes mellitus. Clin Chim Acta., 476:98-102.
14. Farr E, Olivia $M$, and Christos S (2018): A preliminary study." Diabetes, obesity \& metabolism . 20(10)2500-2503.

15. Verras CG, Christou GA, Simos YV et al. (2017): Serum fetuin-A levels are associated with serum triglycerides before and 6 months after bariatric surgery. Hormones (Athens), 16(3):297-305.

16. Šimják $P$, Cinkajzlová $A$, Anderlová $K$ et al. (2018): Changes in plasma concentrations and mRNA expression of hepatokines fetuin-A, fetuin-B and FGF21 in physiological pregnancy and gestational diabetes mellitus. Physiol Res., 67(3):531-542.

17. Ammar SR, Elbedewy TA, Nagy HM et al. (2017): Relationship between serum Fetuin-A and insulin resistance in patients with hyperthyroidism. Tanta Medical Journal, 45 (3)135-140.

18. Shimoda M, Kaneto H, Yoshioka $H$ et al. (2016): Influence of atherosclerosis-related risk factors on serum high-sensitivity C-reactive protein levels in patients with type 2 diabetes: Comparison of their influence in obese and non-obese patients. J Diabetes Investig., 7(2): 197-205.

19. Liang YL, Cai WJ, Zhu LY et al. (2015): Association of plasma Fetuin-A and clinical characteristics in patients with new-onset type 2 diabetes mellitus. Int $\mathbf{J}$ Clin Exp Med., 8(1):991-999. 